\section{BANK : STUDI KOMPARATIF ANTARA EKONOMI KONVENSIONAL DAN EKONOMI ISLAM}

\section{Febri Delmi Yetti}

Fakutas Syari'ah dan Ilmu Hukum Uin Suska Riau

\section{Abstract}

BANK : A Comparative Study between Conventional and Islamic Economics: The failure of conventional economics systems is a main factor contributing the discourse of Islamic economics. This can be seen from the economic crisis starting from 1970s to now in the world. If it is examined in a depth, this failure is due to an ineffectiveness of macroeconomic. In fact, in macroeconomic, any economic policy should cause bright result, welfare and justice. In this context, it is needed to study the concept of macroeconomic from the perspective of Islam and conventional. Syariah Bank which is operated by using profit sharing is not allowed to use interest. This is effective to face any monetary problems though there are some weaknesses such as the lack of supporting facilities, the lack of initiatives and the presence of moral bazard..

Keywords: Conventional Bank, Syari'ah Bank, and Islamic economics.

\section{Pendahuluan}

Kegagalan sisitem ekonomi Konvensional merupakan faktor utama pendorong maraknya wacana tentang ekonomi Islam. Setidaknya kegagalan tersebut telah dibuktikan dengan kondisi terpuruknya ekonomi yang dialami banyak negara - negara di dunia sejak tahun 1970 bahkan sampai saat ini. Walaupun bukan tanpa pujian, sistem ekonomi konvensional ternyata tetap tidak mampu berbuat apa- apa untuk mengantarkan sebuah negara ke pintu gerbang kesejahteraan yang diidamkan. Negara berprediket maju seperti Amerika dan sebagian besar negara Eropa sampai saat inipun tetap tidak bisa berbuat apa- apa mengatasi pengangguran, inflasi, hutang negara, kemiskinan, defisit anggaran dan sebagainya.

Kalau ditelaah lebih dalam lagi, kegagalan ini tidak lain disebabkan oleh formula makro ekonomi yang terbukti tidak manjur. Padahal dalam tatanan makro, seharusnya kebijakan ekonomi apapun yang diterapkan harus mampu membuahkan hasil yang cemerlang, menciptakan kemakmuran dan kesejahteraan. Dalam konteks in dipandang perlu untuk mengkaji konsep ekonomi makro dalam perspektuif Islam dan konvensional. Sadono Sukirno dalam bukunya "teori makro ekonomi" mengatakan bahwa kebijakan moneter adalah langkah - langlah yang dijalankan oleh bank sentral untuik mengawasi jumlah uang beredar di tangan masyarakat. Menurut UU No. 23/1999 tentang Bank Indonesia, kebijakan moneter adalah kebijakan yang ditetapkan dan dilaksanakan oleh bank Indonesia untuk mencapai dan memelihara kestabilan nilai rupiah, yang dilakukan antara lain melalui pengendalian jumlah uang beredar dan atau suku bunga. Bank sentral bertindak sebagai agen keuangan pemerintah dan penyimpan dana negara. Bank sentral menerbitkan mata uang, memegang cadangan emas dan berfungsi sebagai tempat simpanan bank-bank lain.

\section{Pengertian dan Defenisi Bank}

Bank bagi masyarakat yang hidup di negara-negara maju, sudah merupakan kebutuhan dasar yang harus dipenuhi. Bank merupakan mitra dalam rangka memenuhi semua kebutuhan keuangan mereka sehari-hari. Bank dijadikan sebagai tempat untuk melakukan berbagai transaksi yang berhubungan dengan keuangan seperti tempat mengamankan uang, melakukan investasi, pengiriman uang, melakukan pembayaran atau melakukan penagihan. Bagi suatu negara bank dapat dikatakan sebagai darahnya perekonomian suatu negara. 
Oleh karena itu, peranan perbankan sangat mempengaruhi kegiatan ekonomi suatu negara. Dengan kata lain kemajuan suatu bank di suatu negara,dapat pula dijadikan ukuran kemajuan negara yang bersangkutan.Semakin maju suatu negara, maka semakin besar peranan perbankan dalam mengendalikan negara tersebut. Artinya, kebreadaan dunia perbankan semakin dibutuhkan pemerintah dan masyarakatnya.

Berbeda dengan di negara-negara berkembang, seperti indonesia, pemahaman tentang bank di negeri ini belum utuh. Sebagian masyarakat hanya memahami bank sebatas tempat menyimpan dan meminjam uang belaka. Bahkan terkadang sebagian masyarakat belum memahami fungsi bank seutuhnya, sehingga tidak heran jika pandangan mereka tentang bank sering diartikan secara keliru. Selebihnya banyak masyarakat yang tidak paham sama sekali tentang dunia perbankan. Semua ini tentu dapat dipahami karena pengenalan dunia perbankan secara utuh terhadap masyarakat belumlah optimal, teurtama melalui ilmu pemasaran bank.

Jika ditelusuri lewat sejarah sejak dulu sampai sekarang ini, peranan perbankan dalam memajukan perekonomian suatu negara sangatlah besar. Hampir semua sektor yang berhubungan dengan berbagai kegiatan keuangan selalu membutuhkan jasa bank. Oleh karena itu, saat ini dan dimasa yang akan datang setiap negara dan individu kita tidak akan dapat lepas dari dunia perbankan, jika hendak menjalankan aktivitas keuangan, baik perorangan maupun lembaga, baik sosial atau perusahaan. Begitu pentingnya dunia perbankan, sehingga ada anggapan bahwa bank merupakan "nyawa" untuk menggerakkan roda perekonomian suatu negara. Anggapan ini tentunya tidak salah, karena fungsi bank sebagai lembaga keuangan vital, misalnya dalam hal penciptaan uang, mengedarkan uang, menyediakan uang untuk menunjang kegiatan usaha, tempat mengamankan uang, tempat melakukan investasi dan jasa keuangan lainnya.

Pengertian bank pada awalnya dikenal adalah Banco yang artinya meja atau bangku,lalu pengertian berkembang tempat penyimpanan uang dan seterusnya. Pengertian ini tidaklah salah, karena pengertian pada saat itu sesuai dengan kegiatan bank pada saat itu. Namun semakin modernnya perkembangan dunia perbankan, maka pengertian bank pun berubah pula. Secara sederhana bank diartikan sebagai lembaga keuangan yang kegiatan usahanya adalah penghimpun dana dari masyarakat dan menyalurkan kembali dana tersebut ke masyarakat serta memberikan jasa-jasa bank lainnya. ${ }^{1}$ Sedangkan pengertian lembaga keuangan ialah setiap perusahaan yang bergerak dibidang keuangan dimana kegiatannya baik hanya menghimpun dana, atau hanya menyalurkan dana atau kedua-duanya menghimpun dan menyalurkan dana. ${ }^{2}$

Kemudian pengertian bank menurut Undang-undang RI nomor 10 tahun 1998 tanggal 10 November 1998 tentang perbankan adalah "Badan usaha yang menghimpun dana dari masyarakat dalam bentuk simpanan dan menyalurkannya kepada masyarakat dalam bentuk kredit dan atau bentuk-bentuk lainnya dalam rangka meningkatkan taraf hidup rakyat banyak".

Dari kedua pengertian diatas dapat disimpulkan bahwa bank merupakan lembaga keuangan yang kegiatannya adalah menghimpun dana (funding) dari masyarakat dalam bentuk simpanan, dalam hal ini bank sebagai tempat menyimpan uang atau berinvestasi bagi masyarakat. Tujuan utama masyarakat menyimpan uang biasanya adalah untuk keamanan uangnya.Kemudian untuk melakukan investasi dengan harapan memperoleh bunga dari hasil simpanannya. Tujuan lainnya adalah untuk memudahkan melakukan transaksi pembayaran.

1 Kasmir, Pemasaran Bank, (Jakarta : Prenada Media, 2004), hlm. 8

2 Kasmir, Manajemen Perbankan, (Jakarta : Rajawali Press, 2000), hlm. 12 
Untuk memenuhi tujuan diatas, baik untuk mengamankan uang maupun untuk melakukan investasi, bank menyediakan sarana yang disebut dengan simpanan. Jenis simpanan yang ditawarkan sangat bervariasi tergantung dari bank yang bersangkutan.

Menyalurkan dana (lending) kemasyarakat, dalam hal ini bank memberikan pinjaman (kredit) kepada masyarakat. Dengan kata lain bank menyediakan dana bagi masyarakt yang membutuhkannya. Pinjaman atau kredit yang diberikan dibagi dalam dalam berbagai jenis sesuai dengan keinginan nasabah. Sebelum kredit diberikan bank terlebih dulu menilai apakah kredit tersebut layak diberikan atau tidak. Penilaian ini dilakukan agar bank terhindar dari kerugian akibat tidak dapat dikembalikannya pinjaman yang disalurkan bank dengan berbagai sebab. Jenis kredit yang biasa diberikan oleh hampir semua bank adalah kredit investasi kredit modal kerja, atau kredit perdagangan. Memberikan jasa-jasa bank lainnya (services) seperti pengiriman uang (transfer), penagihan surat-surat berharga yang berasal dari dalam kota (clearing), penagihan surat-surat berharga yang berasal dari kota dan luar negeri (inkaso), letter of credit (L/C), safe deposit box, bank garansi, bank notes, travellers cheque, dan jasa lainnya. Jasa-jasa bank lainnya ini merupakan jasa pendukung dari kegiatan pokok bank yaitu menghimpun dan menyalurkan dana.

Dalam praktiknya bank juga memiliki fungsi sebagai lembaga perantara keuangan antara masyarakat yang kelebihan dana dengan masyarakat yang kekurangan dana. Masyarakat kelebihan dana maksudnya adalah masyarakat yang memiliki dana yang berlebihan kemudian disimpan di bank. Dana yang disimpan di bank aman, karena terhindar dari kehilangan atau kerusakan. Penyimpanan uang di bank disamping aman juga menghasilkan bunga dari uang yang disimpannya oleh bank dana simpanan masyarakat ini disalurkan kembali kepada masyarakat yang kekurangan dana (membutuhkan dana).
Bagi masyarakat yang kekurangan dana atau membutuhkan dana dalam rangka membiayai suatu usaha atau kebutuhan rumah tangga mereka dapat menggunakan pinjaman ke bank. Pada bank konvensional akan memperoleh keuntungan dari selisih bunga yang diberikan kepada penyimpan (bunga simpanan) dengan bunga yang diterima dari peminjam (bunga kredit). Keuntungan ini dikenal dengan istilah spread based. Sedangkan bagi bank syraiah tidak dikenal istilah bunga, keuntungan yang diperoleh dikenal dengan bagi hasil.

\section{Jenis-jenis Bank}

Praktik perbankan di Indonesia saat ini yang diatur dalam Undang-undang perbankan memiliki beberapa jenis bank. Di dalam Undang-undang perbankan nomor 10 tahun1998 dengan sebelumnya yaitu Undang-undang nomor 14 tahun 1967, terdapat beberapa jenis perbankan. Perbedaan jenis perbankan dapat dilihat dari segi fungsi, kepemilikan dan dari segi menentukan harga. Dari segi fungsi perbedaan yang terjadi terletak pada luasnya kegiatan atau jumlah produk yang dapat ditawarkan maupun jangkauan wilayah operasinya. Kemudian kepemilikan perusahaan dilihat dari segi pemilikan saham yang ada serta akte pendiriannya. Sedangkan dari menentukan harga yaitu bank konvesional berdasarkan bunga dan bank syariah berdasarkan bagi hasil.

Untuk jelasnya jenis perbankan dewasa ini dapat ditinjau dari berbagai segi antara lain :

Dilihat dari segi fungsinya. Dalam Undang-undang pokok perbankan nomor 14 tahun 1967 jenis perbankan menurut fungsinya terdiri dari; [a] Bank umum, [b] Bank pembangunan, [c] Bank tabungan, [d] Bank pasar, [e] Bank desa, [f] Lumbung desa, dan [g] Bank pegawai.

Kemudian menurut Undang-undang pokok perbankan nomor 7 tahun 1992 dan ditegaskan lagi dengan keluarga Undang-undang 138 
nomor 10 tahun 1990 maka jenis perbankan terdiri dari dua jenis bank yaitu; [a] Bank Umum, dan [b] Bank Perkreditan Rakyat (BPR).

Dengan keluarnya Undang-undang nomor 7 tahun 1992 tersebut mengakibatkan perubahan fungsi Bank Pembangunan dan Bank Tabungan menjadi Bank Umum. Sedangkan, Bank desa, Bank Pasar, Lumbung Desa dan Bank Pegawai menjadi Bank Perkreditan Rakyat (BPR). Bank umum dan BPR memiliki beberapa perbedaan untuk lebih jelasnya berikut ini akan diuraikan lebih lanjut. Pengertian Bank Umum sesuai dengan Undang-undang nomor 10 tahun 1998 adalah bank yang melaksanakan kegiatan usaha secara kegiatannya memberikan jasa dalam lalu lintas pembayaran. Bank Umum sering disebut Bank Komersil (Commercial Bank). Sedangkan pengertian BPR menurut Undang-undang nomor 10 tahun 1998 adalah bank yang melaksanakan kegiatan usaha secara konversial atau berdasarkan prinsip syariah yang dalam kegiatannya tidak memberikan jasa dalam lalu lintas pembayaran.

Artinya disini kegiatan BPR jauh lebih sempit jika dibandingkan dengan kegiatan bank umum. Kegiatan BPR hanya meliputi kegiatan penghimpunan dan penyaluran dana saja, bahkan dalam menghimpun dana BPR dilarang untuk menirima simpanan giro. Begitu pula dalam hal jangkauan wilayah operasi, BPR hanya dibatasi dalam wilayahwilayah tertentu saja. Selanjutnya pendirian BPR dengan modal awal yang relatif lebih kecil jika dibandingkan dengan modal awal bank umum. Larangan lainnya BPR adalah tidak diperkenankan ikut kliring serta transaksi valuta asing. ${ }^{3}$ Disamping kedua jenis bank diatas dalam praktiknya masih terdapat satu lagi jenis bank yang ada di indonesia yaitu Bank sentral. Jenis bank ini bersifat tidak komersial seperti halnya bank umum dan BPR. Bahkan disetiap negara jenis ini selalu ada dan di Indonesia fungsi bank sentral ini diatur Undang-undang

3 Ibid, hlm. 22 nomor 23 tahun 1999 tentang Bank Indonesia.

Tujuan Bank Indonesia tertuang dalam Undang-undang nomor 23 tahun 1999 bab III pasal 7 adalah untuk mencapai dan memelihara kestabilan nilai rupiah ${ }^{4}$ mata uang rupiah perlu dijaga dan dipelihara mengingat dampak yang ditimbulkan apabila suatu mata uang tidak stabil sangatlah luas seperti salah satunya adalah terjadinya inflasi yang sangat memberatkan masyarakat luas. Oleh karena itu tugas Bank Indonesia untuk mencapai dan memelihara kestabilan nilai rupiah sangatlah penting.

Adapun maksud dari kestabilan rupiah yang diinginkan oleh Bank Indonesi adalah sebagai berikut : Kestabilan nilai rupiah terhadap barang dan jasa yang dapat diukur dengan atau tercermin dari perkembangan laju inflasi.Kestabilan nilai rupiah terhadap mata uang negara lain. Hal ini dapat diukur dengan atau tercermin dari perkembangan nilai tukar rupiah terhadap mata uang negara lain. Dengan stabilnya nilai mata uang rupiah, maka akan sangat banyak manfaat yang akan diperoleh terutamaa untuk mendukung pembangunan ekonomi yang bekelanjutan dan meningkatkan kesejahteraan rakyat agar kestabilan nilai rupiah dapat tercapai dan terpelihara, maka Bank Indonesi memiliki tugas antara lain; [a] Menetapkan dan melaksanakan kebijakan moneter, [b] Mengatur dan menjaga kelancaran sistem pembayaran, dan [c] Mengawasi Bank. ${ }^{5}$

Dilihat dari segi Kepemilikannnya, maksudnya adalah siapa saja yang memiliki bank tersebut. Kepemilikan ini dapat dilihat dari akte pendiri dan penguasaan saham yang dimiliki bank yang bersangkutan. Jenis bank dilihat dari segi kepemilikan adalah sebagai berikut; [a] Bank Milik Pemerintah, seperti Bank Negara Indonesia (BNI) 46,

4 Raachibini, Didik, Bank Indonesia Menuju Indepedensi Bank Sentral, Jakartaa : Mardimulyo, 2009), hlm. 167

5 Ibid, hlm.113-162 
Bank Rakyat Indonesia (BRI), Bank Tabungan Negara (BTN), Bank Mandiri, Bank Riau, Bank Pemerintah Daerah (BPD). [b] Bank Milik Swasta Pemerintah Nasional Merupakan Bank yang seluruhnya atau sebagian besarnya dimiliki oleh swasta nasional serta akte pendiriannya pun didirikan oleh swasta, begitu pula pembagian keuntungannya diambil oleh swasta pula, seperti Bank Bumi Putra, Bank BUKOPIN, Bank Central Asia, Bank Panin, Bank Niaga, Bank Danamon, BII, Bank LIPPO, Bank Muamalat. [c] Bank Milik Asing, merupakan Bank yang ada diluar negeri baik milik swasta asing maupun pemerintah asing suatu negara, seperti ABN AMRO Bank, City Bank, Century Bank, Chase Manhattan Bank, Bank of Amerika. [d] Bank Milik Campuran, merupakan Bank yang kepemilikan sahamnya dimiliki oleh pihak asing dan pihak swasta nasional. Dimana kepemilikan sahamnya secara mayoritas dipegang oleh warga negara Indonesia. Seperti, Bank Finconesia, Bank Merincorp, Sumitomo Niaga Bank, Mitshubitshi Buana Bank. ${ }^{6}$

Dilihat dari segi Status. Pembagian jenis bank dari segi status merupakan pembagian berdasarkan kedudukan atau status Bank tersebut. Kedudukan atau status ini menunjukkan ukuran kemampuan Bank dalam melayani masyarakat baik dari segi jumlah produk modal maupun kualitas pelayanannya. Oleh karena itu untuk memperoleh status tersebut diperlukan penilaian-penilaian dengan kriteria khusus untuk Bank umum. Dalam praktiknya jenis Bank dilihat dari status dibagi dua macam : [a] Bank Devisa, yakni Bank yang dapat melaksanakan transaksi ke luar negeri atau yang berhubungan dengan mata uang asing secara keseluruhan, misalnya transfer ke luar negeri, inkaso ke luar negeri, traveller cheque, pembukaan dan pembayaran letter of credit (L/C) dan transaksi luar negeri lainnya. [b] Bank Non Devisa, yakni merupakan Bank yang belum mempunyai izin untuk melaksanakan transaksi sebagai bank devisa, sehingga tidak dapat

6 Kasmir, op.cit., hlm.26-29 melaksanakan transaksi seperti halnya Bank devisa. Jadi Bank non devisa merupakan kebalikan dari bank devisa, dimana transaksi yang dilakukan masih dalam batas-batas suatu negara. ${ }^{7}$

Dilihat dari segi cara menentukan harga. Jenis Bank jika dilihat dari segi atau caranya dalam menentukan harga baik harga jual maupun harga beli terbagi dalam 2 kelompok yaitu, [a] Bank yang berdasarkan prinsip konvensional, dan [b] Bank berdasarkan prinsip syariah.

Mayoritas Bank yang berkembang di Indonesia dewasa ini adalah Bank yang berorientasi pada prinsip konvensional hal ini disebabkan tidak terlepas dari sejarah bangsa Indonesia dimana asal mula Bank di Indonesia dibawa oleh kolonial belanda (barat). Dalam mencari keuntungan dan menentukan harga kepada para nasabahnya,bank yang berdasarkan prinsip konvensional menggunakan dua metode, yaitu, Menetapkan bunga sebagai harga jual, baik untuk produk simpanan seperti giro, tabungan maupun deposito. Demikian pula harga beli untuk produk pinjaman (kredit) juga ditentukan berdasarkan tingkat suku bunga tertentu. Penentuan harga ini di kenal dengan istilah spread based. Untuk jasa-jasa bank lainnya, pihak perbankan konvensional menggunakan atau merupakan berbagai biaya-biaya dalam nominal atau persentase tertentu seperti biaya administrasi, biaya provisi, sewa, iuran dan biaya-biaya lainnya. Sistem pengenaan biaya ini dikenal dengan istilah fee based

Bank berdasarkan prinsip syariah menerapkan aturan perjanjian berdasarkan hukum Islam antara Bank dengan pihak lain dalam hal untuk menyimpan dana atau pembiayaan usaha atau kegiatan perbankan lainnya. Penentuan harga atau mencari keuntungan bagi Bank yang berdasarkan prinsip syariah adalah dengan cara [1] Pembiayaan berdasarkan prinsip bagi hasil (mudharabab), [2]

7 Ibid, hlm. 29-30 
Pembiayaan berdasarkan prinsip penyertaan modal (musyarakah), [3] Prinsip jual beli barang dengan memperoleh keuntungan (murabahah), [4] Pembiayaan barang modal berdasarkan sewa murni tanpa pilihan (ijarah), [5] atau dengan adanya pilihan pemindahan kepemilikan atas barang yang disewa dari pihak bank oleh pihak lain (jjarah wa iqtina). ${ }^{8}$ Sedangkan penentuan biaya-biaya jasa Bank lainnya bagi Bank yang berdasarkan prinsip syariah juga sesuai syariah Islam. Kemudian sumber penentuan harga atau pelaksanaan kegiatan Bank prinsip syariah dasar hukumnya adalah al-Qur'an dan Sunnah Rasul. Bank berdasarkan prinsip syari'ah mengharamkan penggunaan harga produknya dengan prinsip bunga.

\section{Jenis-Jenis Produk Bank Syariah}

Kita sudah menggolongkan bahwa produk Bank merupakan jasa, kemudian jasa yang ditawarkan dalam bentuk beraneka ragam. Dalam praktik sehari-hari berbagai jenis jasa Bank ditawarkan kepada masyarakat. Kelengkapan jenis produk yang ditawarkan sangat tergantung dari kemampuan Bank dan jenis Bank itu sendiri, misalnya Bank umum lebih lengkap dari BPR atau Bank devisa lebih lengkap jika dibandingkan dengan Bank Non Devisa. Semakin lengkap produk yang ditawarkan akan semakin baik, sehingga untuk memperoleh produk Bank nasabah cukup mendatangi satu Bank saja.

Jenis-jenis produk Bank yang akan dibahas dalam tulisan ini hanya jenis-jenis produk Bank konvensial dan jenis-jenis produk Bank Syariah.

Produk-produk Bank Konvensial meliputi; [a] Menghimpun dana dari masyarakat (funding) dalam bentuk, [b] Simpanan Giro, [c] Rekening giro atas nama perorangan maupun atas nama badan usaha, [d] Simpanan tabungan (saving deposit), [e] Simpanan Deposit (Time

8 Ibid, hlm. $30-31$ deposit), [e] Menyalurkan dana kemasyarakat (lending) dalam bentuk kredit, [f] Memberikan jasa-jasa bank lainnya (services) seperti Pembayaran pajak, Pembayaran telepon, Pembayaran air, Pembayaran listrik, Pembayaran uang kuliah, Gaji / pensiun / honorarium, Pembayaran deviden, Pembayaran kupon, Penjamin klemisi (underwriter), Penanggung (guarantor), Wali perdagangan efek (pialang / broker), Pedagang efek (dealer), Perusahaan pengelola dana (Investment company), Transfer (kiriman uang), Inkaso (collection), Kliring, Safe deposito box, Bank card, Bank notes (valas), Bank garansi, Referensi bank, Bank draft, Letter of credit (L/C), Cek wisata (Travellers cheque), dan jasa lainnya.

\section{Jenis-jenis Produk Bank Syariah}

Pada dasarnya, produk yang ditawarkan oleh perbankan syariah dapat dibagi menjadi tiga bagian besar, yaitu; [a] Produk penyaluran dana (Financing), [b] Produk penghimpunan dana (Funding), dan [c] Produk jasa (service) : 9

\section{Produk penyaluran dana (Financing)}

Dalam penyaluran dananya kepada nasabah, secara garis besar produk pembiayaan syariah terbagi ke dalam empat kategori yang dibedakan tujuan penggunaan, yaitu; [a] Pembiayaan dengan prinsip jual beli, [b] Pembiayaan dengan prinsip sewa, [c] Pembiayaan dengan prinsip bagi hasil, dan [d] Pembiayaan dengan akad pelengkap. ${ }^{10}$

Pembiayaan dengan prinsip jual beli ditujukan untuk memiliki barang sedangkan yang menggunakan prinsip bagi hasil digunakan untuk usaha kerja sama yang ditujukan guna mendapatkan barang dan

9 Karim, Adiwarman, Bank Islam, (Jakarta : Rajawali Press, 2007), hlm. 97 $10 \mathrm{Ibid}$, hlm. 
jasa sekaligus. Pada kategori pertama dan kedua, tingkat keuntungan bank ditentukan didepan dan menjadi bagian harga atas barang atau jasa yang dijual produk yang termasuk dalam kelompok ini adalah produk yang menggunakan prinsip jual beli seperti murabahah, salam, dan istishna serta produk yang menggunakan prinsip sewa, yaitu ijarah dan IMBT. Sedangkan pada kategori ketiga, tingkat keuntungan bank ditentukan dari besarnya keuntungan usaha sesuai dengan prinsip bagi hasil. Pada produk bagi hasil keuntungan ditentukan oleh nisbah bagi hasil yang disepakati dimuka. Produk perbankan yang termasuk kedalam kelompok ini adalah masyarakat dan mudharabah. Sedangkan pembiayaan dengan akad pelengkap ditujukan untuk memperlancar pembiayaan dengan menggunakan tiga prinsip diatas. Kita akan membahas masing-masing produk ini dengan lebih rinci pada uraian berikut;

Prinsip Jual Beli (Ba'i) dilaksanakan sehubungan dengan adanya perpindahan kepemilikan barang atau benda (transfer of property). Tingkat keuntungan bank ditentukan di depan dan menjadi bagian harga atas barang yang dijual. Transaksi jual beli dapat dibedakan berdasarkan bentuk pembayarannya dan waktu penyerahan barangnya, yakni sebagai berikut;

Pembiayaan Murabahah, Murabahah berasal dari kata ribhu (keuntungan), adalah transaksi jual beli dimana bank menyebutkan jumlah keuntungannya. Bank bertindak sebagai penjual, sementara nasavah sebagai pembeli. Harga jual adalah harga beli bank dari pemasok ditambah keuntungan (margin). Kedua belah pihak harus menyepakati harga jual dan jangka waktu pembayaran. Harga jual dicantumkan dalam akad jual beli dan jika telah disepakati tidak dapat berubah selama berlakunya akad. Dalam perbankan murabahah selalu dilakukan dengan cara pembayaran cicilan. Dalam transaksi barang diserahkan segera setelah, akad, sementara pembayaran dilakukan secara tangguh/cicilan. Pembiayaan murabahah ini akan dibahas lebih rinci pada sub bab tentang jenis-jenis pembiayaan.

Pembiayaan Salam, Salam adalah transaksi jual beli dimana barang yang diperjual belikan belum ada. Oleh karena itu, barang diserahkan secara tangguh sementara pembayaran dilakukan tunai. Bank bertindak sebagai pembeli, sementara nasabah sebagai penjual. Sekilas transaksi ini mirip jual beli ijon, namun dalam transaksi ini kuantitas, kualitas harga dan waktu penyerahan barang harus ditentukan secara pasti. Dalam praktik perbankan, ketika barang telah diserahkan kepada bank, maka bank akan menjualnya kepada rekanan nasabah atau nasah itu sendiri secara tunai atau secara cicilan. Harga jual yang ditetapkan oleh bank adalah harga beli bank dari nasabah ditambah keuntungan. Dalam hal bank menjualnya secara tunai biasanya disebut pembiayaan talangan (bridging financing). Sedangkan dalam hal bank menjualnya secara cicilan, keuda pihak harus menyepakati harga jual dan jangka waktu pembayaran. Harga jua dicantumkan dalam akad jual beli dan jika telah disepakati tidak dapat berubah selama berlakunya akad. Umumnya transaksi ini diterapkan dalam pembiayaanbarang yang belum ada seperti pembelian komoditi pertanian oleh bank untuk kemudian dijual kembali secara tunai atau secara cicilan.

Ketentuan umum pembiayaan salam sebagai berikut; Pembelian hasil produksi harus diketahui spesifikasinya secara jelas seperti jenis macam, ukuran, mutu dan jumlahnya. Misalnya jual beli $100 \mathrm{~kg}$ mangga harum - manis kualitas A dengan harga Rp. 5000/kg akan diserahkan pada panen dua bulan mendatang. Apabila hasil produksi yang diterima cacat atau tidak sesuai dengan akad maka nasabah (prosedun) harus bertanggung jawab dengan cara antara lain mengembalikan dana yang telah diterimanya atau mengganti barang yang sesuai dengan pesanan. Mengingat bank tidak menjadikan barang yang dibelikan atau dipegangnya sebagai persediaan (investory). Maka dimungkinkan bagi bank untuk melakukan akad salam kepada pihak 
ketiga (pembeli kedua), seperti BULOG, pedagang pasar induk atau rekanan. Mekanisme seperti ini disebut dengan salam paralel.

Pembiayaan Istishna, Produk istishna menyerupai produk salam, tapi dalam istihna pembayarannya dapat dilakukan oleh bank dalam beberapa kali (kermin) pembayaran, skim istishna dalam bank syariah umumnya diaplikasikan pada pembiayaan manufaktur dan konstruksi. ${ }^{11}$

Prinsip Sewa (Ijarah), Transaksi ijarah dilandasi adanya perpindahan manfaat jadi pada dasarnya prinsip ijarah sama saja dengan prinsip jual beli, perbedaannya terletak pada objek transaksi. Bila pada jual belim objek transaksinya adalah barang, pada ijarah objek transaksinya adalah jasa. Pada akhir masa sewa, bank dapat saja menjual barang yang disewakannya kepada nasabah karena itu dalam perbankan syariah dikenal ijarah muntabhiyah gittamlik (sewa yang diikuti dengan berpindahnya kepemikan). Harga sewa dan harga jual disepakati pada awal perjanjian. Pembiayaan ijarah dan IMBT ini akan dibahas lebih rinci pada sub bab mengenai jenis-jenis pembiayaan. ${ }^{12}$

Prinsip bagi Hasil (Syirkah), Produk pembiayaan syariah yang didasarkan atas prinsip bagi hasil adalah sebagai berikut; Pembiayaan Musyarakah. Bentuk umum dari usaha bagi hasil adalah musyarakah. Transaksi musyarakah dilandasi adanya keinginan para pihak yang bekerja sama untuk meningkatkan nilai aset yang mereka miliki secara bersama-sama. Semua bentuk usaha yang melibatkan dua pihak atau lebih dimana mereka secara bersama-sama memadukan seluruh bentuk sumber daya baik yang berwujud maupun tidak berwujud. Secara spesifik bentuk kontribusi dari pihak yang bekerja sama dapat berupa dana, barang perdagangan (Trading asset), kewiraswastaan (entrespreneurship), kepandaian (skill), kepemilikan (property), peralatan (equipment), atau intangible asset (seperti hak paten atau good will), kepercayaan/reutasi (creditwortbiness) dan barang-barang lainnya yang dapat dinilai dengan uang. Dengan merangkum seluruh kombinasi dari bentuk kontribusi masing-masing pihak dengan atau taanpa batasan waktu menjadikan produk ini sangat fleksibel.

Ketentuan umum pembiayaan musyawara adalah sebagai berikut; Semua modal disatukan untuk dijadikan modal poyek musyawarah dan dikelola bersama-sama. Setiap pemilik modal berhak turut serta dalam menentukan kebijakkan usaha yang dijalankan oleh pelaksanaan proyek. Biaya yang akan dijalankan harus disebutkan dalam akad.

Pembiayaan Mudharabah, Secara spesifik terdapat bentuk musyarakah yang populer dalam produk perbankan syariah yaitu mudharabah. Mudharabah adalah bentuk kerja sama antara dua atau lebih pihak dimana pemilik modal (shahib al-maal) mempercayakan sejumlah modal kepada pengelola (modharib) dengan suatu perjanjian pembagian keuntungan. Bentuk ini menegaskan kerjasama dalam paduan kontribusi $100 \%$ modal kas dari shabib al - maal dan keahlian dari mudharib. ${ }^{13}$ Transaksi jenis ini tidak mensyaratkan adanya wakil shabib al - maal dalam manajemen proyek. Sebagai orang kepercayaan, mudharib harus bertindak hati-hati dan bertanggung jawab juntuk setiap kerugian yang terjadi akibat kelalaian. Sedangkan sebagai wakil shabib al - maal, mudharib diharapkan untuk mengelola modal dengan cara tertentu untuk menciptaan laba optimal.

Perbedaan yang essesial dari musyarakah dan nudharabah terletak pada besarnya kontribusi atas manajemen dan keuangan atau salah satu diantara itu. Dalam nudharabah, modal hanya berasal dari satu pihak, sedangkan dalam musyarakah modal berasal dari dua pihak atau lebih. Musyarakah dan nudharabah dalam literatur fiqh berbentuk

\section{Ibid}


perjanjian kepercayaan yang menuntut tingkat kejujuran yang tinggi dan menjunjung keadilan. Karenanya masing-masing pihak harus menjaga kejujuran untuk kepentingan bersama dan setiap usaha dari masing-masing pihak untuk melakukan kecurangan dan ketidakadilan pembagian pendapatan betul-betul akan merusak ajaran Islam.

Ketentuan umum pembiayaan nudharabah adalah sebagai berikut; Jumlah modal yang diserahkan kepada nasabah selaku pengelola modal harus diserahkan tunai, dan dapat berupa uang atau barang yang dinyatakan nilainya dalam satuan uang. Apabila modal diserahkan secara bertahap, harus jelas tahapannya dan disepakati bersama. Hasil dari pengelolaan modal pembiayaan nudharabah dapat diperhitungkan dengan cara; Perhitungan dari pendapatan proyek (revenue sharing) dan Perhitungan dari keuntungan proyek (profit sharing). Hasil usaha dibagi sesuai dengan persetujuan dalam akad pada setiap bulan atau waktu yang disepakati. Bank selaku pemilik modal menanggung seluruh kerugian kecuali akibat kelalaian dan penyimpangan pihak knasabah, seperti penyelewengan, kecurangan dan penyalahgunaan dana. Bank berhak melakukan pengawasan terhadap pekerjaan namun tidak berhak mencampuri jurusan pekerjaan/usaha nasabah. Jika nasabah cedera janji dengan sengaja, misalnya tidak mau membayar kewajiban atau menunda pembayaran kewajiban, kmaka ia dapat dikenakan sanksi administratif.

Akad Perlengkapan, Untuk mempermudah pelaksanaan pembiayaan biasanya diperlukan juga akad perlengkapan. Akad perlengkapan ini tidak ditujukan untuk mencari keuntungan, tap ditujukan untuk mempermudah pelaksanaan pembiayaan. Meskipun tidak ditujukan untuk mencari keuntungan, dalam akad perlengkapan ini dibolehkan untuk meminta pengganti biaya-biaya yang dikeluarkan untuk melaksanakan akad ini. Besarnya pengganti biaya ini sekedar nuntuk menutupi biaya yang benar-benar timbul. Akad perlengkapan ini adalah akad-akad tabarru'. Untuk berikut ini akan membahas akad- akad perlengkapan ini.

Hiwalah (alih utang-piutang), Tujuan fasilitas biwalah adalah untuk membantu supplier mendapatkan modal tunai agar dapat melanjutkan produksinya. Bank mendapat ganti biaya atas jasa pemindahan piutang. Untuk mengantisipasikan resiko kerugiaan yang akan timbul, bank perlu melakukan penelitian atas kemampuan pihak yang berutang dan kebenaran transaksi antara yang memindahkan piutang dengan yang berutang. Katakanlah seorang supplier bahan bangunan menjual barangnya kepada kepemilik proyek yang akan dibayar dua bulan kemudian karena kebutuhan supplier akan likuiditas, maka ia meminta bank untuk mengambil alih piutang. Bahkan akan menerima pembayaran dari pemilik proyek.

Rahn (gadai), Tujuan akad rahn adalah untuk memberikan jaminan pembayaran kembali kepada bank dalam memberikan pembiayaan. Barang yang digadaikan wajib memenuhi kriteria; Milik nasabah sendiri; Jelas ukuran, sifat dan nilainya ditentukan berdasarkan nilai riil pasar; Dapat dikuasai namun tidak boleh dimanfaatkan bank. Atas izin bank, nasabah dapat menggunakan barang tertentu digadaikan dengan tidak mengurangi nilai dan merusak barang yang digadaikan. Apabila barang yang digadaikan rusak atau cacat nasabah harus bertanggung jawab. Apabila nasabah wan prestasi, bank dapat melakukan penjualan barang yang digadaikan atas perintah hakim. Nasabah mempunyai hak untuk menjual barang tersebut dengan seizin bank. Apabila hasil penjual kmelebihi kewajibannya, kelebihan tersebut menjadi milik nasabah. Dalam hasil penjualan tersebut lebih kecil dari kewajibannya, maka nasabah harus menutupi kekurangannya.

Qardh, Qadar adalah pinjaman uang Aplikasi qard dalam perbankan biasanya dalam empat hal, yaitu : [a] Sebagai pinjaman talangan haji; [b] Sebagai pinjaman tunai dari produk kartu kredit syariah; [c] Sebagai pinjaman kepada pengusaha kecil; [d] Sebagai 150 
pinjaman kepada pengurus bank.

Wakalah (Perwakilan), Wakalah dalan aplikasi perbankan terjadi apabila nasabah memberikan kuasa kepada bank untuk mewakili dirinya melakukan pekerjaan jasa tertentu, seperti pembukaan L/C, inkaso dan transfer uang. Bank dan nasabah yang dicantumkan dalam akad pemberian kuasa harus cakap hukum. Khusus untuk pembukaan $\mathrm{L} / \mathrm{C}$, apabila dana nasabah ternyata tidak cukup, maka penyelesaian L/C dilakukan dengan pembiayaan murababah, salam, ijarah, mudharabah, atau musyarakah. Kelalaian dalam menjalankan kuasa menjadi tanggung jawab bank, kecuali kegagalan karena force majeury menjadi tanggung jawab nasabah. Apabila bank yang ditunjuk lebih dari satu, maka masing-masing bank tidak boleh bertindak sendirisendiri tanpa musyawarah dengan bank yang lain, kecuali dengan seizin nasabah. Tugas, wewenang, dan tanggung jawab bank harus jelas sesuai kehendak nasabah bank. Setiap tugas yang dilakukan harus mengatasnamakan nasabah dan harus dilaksanakan oleh bank. Atas pelaksanaan tugasnya tersebut, bank mendapat pengganti biaya berdasarkan kesepakatan bersama. Pemberian kuasa berakhir setelah tugas dilaksanakan dan disetujui bersama antara nasabah dengan bank.

Kafalah (Garansi Bank), Garansi bank dapat diberikan dengan tujuan untuk menjamin pembayaran suatu kewajiban pembayaran. Bank dapat mensyaratkan nasabah untuk menempatkan / sejumlah dana untuk fasilitas ini sebagai rahn. Bank dapat pula menerima dana tersebut dengan prinsip wadiah. Untuk jasa-jasa ini, bank mendapatkan pengganti biaya atas jasa yang diberikan. ${ }^{14}$

\section{Produk penghimpunan dana (Funding)}

Penghimpunan dana di bank syariah dapat berbentuk giro, tabungan, dan deposito. Prinsip operasional syariah yang diterapkan

14 Ibid. dalam penghimpunan dana masyarakat adalah prinsip wadiah dan mudharabah.

Prinsip wadi'ah, Prinsip wadi'ah yang diterapkan wadi'ah yad dhamanah yang diterapkan pada produk rekening giro. Wadiah dhamanah berbeeda dengan wadi'ah amanah. Dalam wadi'ab amanah, pada prinsipnya harta titipan tidak boleh dimanfaatkan oleh yang dititipi. Sementara itu dalam hal wadiah dhamanah, pihak yang dititipi (bank) bertanggung jawab atas keutuhan harta titipan sehingga ia boleh memanfaatkan harta titipan tersebut. Karena wadiah yang diterapkan dalam produk giro perbankan ini juga diipati dengan yad dhamanah, implikasi hukumnya sama dengan qardh, dimana nasabah bertindak sebagai yang meminjamkan uang dan bank bertindak sebagai yang dipinjami. Jadi mirip seperti yang dilakukan zubair bin awwan ketika menerima titipan uang dizaman Rasulullah. Ketentuan umum dari produk ini adalah Dana wadi'ah dapat digunakan oleh bank umum untuk kegiatan komersial dengan syarat bank harus menjamin pembayaran kembali nominal dana wadi'ab tersebut. Keuntungan atau kerugian dari penyaluran dana menjadi hak milik atau ditanggung bank, sedangkan pemilik dana tidak dijanjikan imbalan dan tidak menanggung kerugian. Bank dimungkinkan memberikan bonus kepada pemilik dana sebagai suatu insentif untuk menarik dana masyarakat tapi tidak boleh diperjanjikan dimuka. Pemilik dana wadi'ah dapat menarik kembali dananya sewaktu-waktu, baik sebagian ataupun seluruhnya. Bank dapat memberikan bonus atas penitipan dana wadi'ah. Pemberian bonus dimaksud merupakan kewenangan bank dan tidak boleh diperjanjikan dimuka. Bank harus membuat akad rekening yang isinya mencapai izin penyaluran dana yang disimpan dan persyaratan lain yang disepakati selama tidak bertentangan dengan prinsip syariah. Khusus bagi pemilik rekening giro, bank dapat memberikan buku cek, bilyet giro, dan debit card. Terhadap pembukaan rekening ini bank dapat mengunakan pengganti biaya administrasi untuk sekedar menutupi biaya yang benar-benar terjadi. 
Prinsip Mudharabah, Dalam mengaplikasikan prinsip mudharabah, penyimpan atau deposan bertindak sebagai shabibul maal (pemilik modal) dan bank sebagai mudharib (pengelola). Dana tersebut digunakan bank untuk melakukan murabahah atau ijarah seperti yang telah dijelaskan terdahulu. Dapat pula dana tersebut digunakan bank untuk melakukan mudharabah kedua. Maka bank bertanggung jawab penuh atas kerugian yang terjadi. Rukun mudharabah terpenuhi sempurna (ada mudharib, ada pemilik dana, dan usaha yang akan dibagihasilkan, ada nisba, dan ada ijab kabul). Prinsip mudharabah ini dipalikasikan pada produk tabungan berjangka dan deposito berjangka. Berdasarkan kewenangan yang diberikan oleh pihak penyimpan dana, prinsip mudharabah terbagi dua yaitu : [a] Mudaharabah mutlaqah atau URIA (Unrestricted Investment Account), dan [b] Mudharabah muqayyadah atau RIA (Restricted Investment Account)

Mudaharabah Mutlaqah (URIA), Dalam mudharabah mutlaqah tidak ada pembatasan bagi bank dalam menggunakan dana yang dihimpun. Nasabah tidak memberikan persyaratan apapun kepada bank, kebisnis apa dana yang disimpannya itu hendak disalurkan atau menetapkan penggunaan akad-akad tertentu, ataupun mensyaratkan dananya diperuntukkan bagi nasabaha tertentu. Jadi bank memiliki kebebasan penuh untuk menyalurkan dana URIA ini ke bisnis manapun yang diperkirakan menguntungkan. Dari penerapan mudharabah mutlaqah ini dikembangkan produk tabungan dan deposito, sehingga terdapat dua jenis penghimpunan dana, yaitu tabungan mudharabah dan deposito mudharabah.

Mudharabah Muqayyadah (RIA), Mudharabah muwayyaddah ini dua jenis, yaitu ; [a] Mudharabah muqayyadah on balance sheet, dan [b] Mudharabah muqayyadah of balance sheet. Jenis mudharabah ini merupakan simpanan khusus dimana pemilik dana dapat menetapkan syarat-syarat tertentu yang harus dipatuhi oleh bank. Misalnya disyaratkan digunakan untuk bisnis tertentu atau disyaratkan digunakan dengan akad tertentu, atau disyaratkan digunakan untuk nasabah tertentu. Jenis mudharabah ini merupakan penyaluran dana mudharabab langsung kepada pelaksana usahanya, dimana bank bertindak sebagai perantara yang mempertemukan antara pemilik dana dengan pelaksana usaha. Pemilik dana dapat menetapkan syarat-syarat tertentu yang harus dipatuhi oleh bank dalam mencari bisnis (pelaksana usaha). ${ }^{15}$

Akad Pelengkap, Seperti yang juga terjadi pada penyaluran dana, maka dalam pelaksanaan penghimpunan dana, biasanya diperlukan juga akad pelengkap. Akad pelengkap ini juga tidak ditujukan untuk mencari keuntungan, namun ditujukan untuk mempermudah pelaksanaan pembiayaan. Salah satu akad pelengkap yang dapat dipakai untuk penghimpunan dana adalah wakalah. Wakalah adalah aplikasi perbankan terjadi apabila nasabah memberikan kuasa kepada bank untuk mewakili dirinya melakukan pekerjaan jasa tertentu, seperi inkaso dan transfer uang. ${ }^{16}$

\section{Produk Jasa (service)}

Selain menjalankan fungsi sebagai intermediaries antara pihak yang membutuhkan dana dengan pihak yang kelebihaan dana, bank syariah dapat pula melakukan berbagai pelayanan jasa perbankan kepada nasabah dengan mendapat imbalan berupa sewa atau keuntungan jasa perbankanersebut anatra lain berupa :

Sharf (Jual Beli Valuta Asing), Pada prinsipnya jual beli valuta asing sejalan dengan prinsip sharf, jual beli mata uang yang tidak sejenis ini, penyerahan harus dilakukan pada waktu yang sama (spot). Bank mengambil keuntungan dari jual beli valuta asing ini.

Ijarah (Sewa), Jenis kegiatan ijarah antara lain penyewaan kotak 
simpanan (safe deposit box) dan jasa tata laksana administrasi dokumen (custodian). Bank mendapat imbalan sewa dari jasa tersebut. ${ }^{17}$

Kredit, dalam bahasa sehari-hari kata kredit sering diartikan memperoleh barang dengan membayar dengan cicilan atau angsuran dikemudian hari untuk memperoleh pinjaman uang yang pembayarannya dilakukan dikemudian hari dengan cicilan atau angsuran sesuai dengan perjanjian. Jadi, dapat diartikan bahwa kredit berbentuk barang maupun kredit berbentuk uang dalam hal pembayarannya adalah dengan mengunakan metode angsuran atau cicilan tertentu. Kredit dalam bentuk lebih dikenal dengan istilah pinjaman. Dewasa ini pengertian pemberian kredit disamping dengan istilah pinjaman oleh bank yang berdasarkan prinsip kovensional juga adalah pembiayaan yang digunakan oleh bank berdasarkan prinsip syariah. Menurut asal kata kredit berasal dari kata credese yang artinya adalah kepercayaan ${ }^{18}$, maksudnya ialah apabila seseorang memperoleh kredit maka berarti mereka memperoleh kepercayaan. Sedangkan bagi si pemberi kredit artinya memberikan kepercayaan kepada seseorang bahwa uang yang dipinjamkan pasti kembali.

Pengertian kredit menurut Undang-undang perbankan Nomor : 10 tahun 1998 adalah : Penyediaan uang atau tagihan yang dapat dipersamakan dengan itu, berdasarkan persetujuan atau kesepakatan pinjam meminjam antara bank dengan pihak lain yang mewajibkan pihak peminjam melunasi utangnya setelah jangka waktu tertentu dengan pemberian bunga. Sedangkan pengertian pembiayaan adalah penyediaan atau tagihan yang dapat dipersamakan dengan itu, berdasarkan persetujuan atau kesepakatan antara bank dengan pihak lain yang mewajibkan pihak yang dibiayai untuk mengembalikan uang atau tagihan tersebut setelah jangka waktu tertentu dengan imbalan

17 Ibid.

18 Kasmir, Dasar-Dasar Perbankan, (Jakarta : Rajawali Press, 2002), hlm. 101 atau bagi hasil. ${ }^{19}$

Dari pengertian diatas dapatlah dijelaskan bahwa baik kredit atau pembiayaan dapat berupa uang atau tagihan yang nilainya diukur dengan uang, misalnya bank membiayai kredit untuk pembelian rumah atau mobil. Kemudian adanya kkesepakatan antara bank (kreditur) dengan nasabah penerima kredit (debitur), dengan perjanjian yang telah dibuatnya. Dalam perjanjian kredit tercakup hak dan kewajiban masing-masing pihak, termasuk jangka waktu serta bunga yang ditetapkan bersama. Demikian pula dengan masalah sangsi apabila si debitur ingkar janji terhadap perjanjian yang telah dibuat bersama. Yang menjadi perbedaan antara kredit yang diberikan oleh bank konvesional dengan pembiayaan yang diberikan oleh bank syariah adalah terletak pada keuntungan yang diharapkan. Bagi bank berdasarkan suku bunga, sedangkan bagi bank syariah keuntungan yang diperoleh berdasarkan imbalan atau bagi hasil. Perbedaan lainnya terdapat pada analisa pembagian kredit beserta persyaratannya.

Analisa kredit diberikan untuk menyakinkan bank bahwa si nasabah benar-benar dapat dipercaya, maka sebelum kredit diberikan bank terlebih dulu mengadakan analisa kredit atas pembiayaan. Analisa kredit atau pembiayaan mencakup latar belakang nasabah atau perusahaan, prospek usaha, jaminan yang diberikan dan faktor-faktor lainnya. Tujuan analisis ini adalah agar bank yakin bahwa kredit yang diberikan benar-benar aman dalam arti uang yang disalurkan pasti kembali. Pemberian kredit tanpa dianlisis terlebih dulu akan sangat membahayakan bank. Masalah dalam hal ini dengan mudah memberikan data-data fiktif sehingga kredit tersebut sebenarnya tidak layak untuk diberikan. Akibatnya jika salah menganalisis, maka kredit yang disalurkan akan sulit untuk ditagih alias macet. Namun faktor salah analisis ini bukanlah merupakan penyebab utama kredit macet
19 Undang-undang No. 10 tahun 1998 tentang Perbankan Pasal 1 ayat 11 - 12 
walaupun sebagian besar kredit macet disebabkan oleh musibah seperti bencana alam yang memang tidak dapat dihindari oleh nasabah. Seperti misalnya kebanjiran atau gempa bumi, atau dapat pula kesalahan dalam pengelolaan. Jika kredit yang disalurkan mengalami kemacetan, maka langkah yang dilakukan oleh bank adalah berupaya untuk menyelamatkan kredit tersebut dengan berbagai cara tergantung dari kondisi nasabah atau penyebab kredit tersebut macet, jika memang masih bisa dibantu, maka tindakan yang dapat dilakukan bank dalam membantu nasabah apakah dengan menambah jumlah kredit atau dengan memperpanjang jangka waktunya. Namun jika memang sudah tidak dapat diselamatkan kembali maka tindakan terakhir bagi bank adalah menyita jaminan yang telah dijaminkan oleh nasabah.

\section{Unsur-unsur Kredit atau Pembiayaan}

Adapun unsur-unsur yang terkandung dalam pemberian suatu fasilitas kredit adalah sebagai berikut; [a] Kepercayaan, [b] Kesepakatan, [c] Jangka Waktu, [c] Resiko, dan [d] Balas Jasa. ${ }^{20}$

Akibat dari pemberian fasilitas kredit bank tentu mengharapkan suatu keuntungan dalam jumlah tertentu. Pada bank konvesional keuntungan atas pemberian suatu kredit ini kita kenal dengan nama bunga. Balas jasa dalam bentuk bunga, biaya provinsi dan komisi serta biaya administrasi kredit ini merupakan keuntungan utama bak. Sedangkan bagi bank syariah balas jasanya ditentukan dengan bagi hasil.

\section{Jenis-jenis Kredit}

Secara umum jenis-jenis yang disalurkan oleh bank dilihat dari

20 Kasmir, Manajemen Perbankan, op, cit, hlm. 75 - 76 berbagai segi ialah. ${ }^{21}$

Dilihat dari segi kegunaan, terdapat dua jenis kredit yaitu; [a] Kredit Investasi, yaitu kredit yang biasnaya digunakan untuk keperluan perluasan usaha atau membangun proyek/pabrik baru dimana masa pemakaiannya untuk satu periode yang relatif lebih lama dan biasanya kegunaan kredit ini adalah untuk kegiatan utama suatu perusahaan; [b] Kredit Modal Kerja, merupakan kredit yang digunakan untuk keperluan meningkatkan produksi dalam operasionanya. Contohnya : kredit modal kerja diberikan untuk membeli bahan baku, membayar gaji pegawai atau biaya-biaya lainnya berkaitan dengan proses produksi perusahaan.

Dilihat dari segi tujuan kredit, terdapat tiga kredit yaitu; [a] Kredit Produktif, yaitu kredit yang digunakan untuk peningkatan usaha atau produksi atau investasi; [b] Kredit Konsumtif, merupakan kredit yang digunakan untuk dikonsumsi atau dipakai secara pribadi; [c] Kredit Perdagangan, merupakan kredit yang digunakan untuk kegiatan perdagangan dan biasanya untuk membeli barang dagangan yang pembayarannya diharapkan dari hasil penjual barang dagangan tersebut.

Dilihat dari segi jangka waktu, terdiri dari tiga jenis kredit, yaitu; [a] Kredit Jangka Pendek, kredit ini merupakan kredit yang memiliki jangka waktu kurang dari 1 tahun; [b] Kredit Jangka Menengah, jangka waktu kreditnya berkisar antara 1 tahun sampai dengan 3 tahun; [c] Kredit Jangka Panjang, merupakan kredit yang masa pengembaliannya paling panjang yaitu diatas 3 tahun atau 5 tahun. Biasanya kredit ini digunakan untuk investasi jangka panjang seperti perkebunan karet, kelapa sawit atau manufaktur dan juga kredit perumahan.

Dilihat dari segi jaminan, terdiri dari; [a] Kredit dengan Jaminan,

\footnotetext{
21 Kasmir, Manajemen Perbankan, op, cit, hlm. 75 - 76
} 
merupakan kredit yang diberikan dengan suatu jaminan tertentu; [b] Kredit tanpa Jaminan, yaitu kredit yang diberikan tanpa jaminan barang tertentu. Kredit jenis ini diberikan dengan melihat prospek usaha, karakter serta loyalitas si calon debitur selama berhubungan dengan bank yang bersangkutan.

Dilihat dari segi sektor usaha, terdiri dari; [a] Kredit pertanian; [b] Kredit peternakan; [c] Kredit industri; [d] Kredit pertambangan; [e] Kredit pendidikan; [f] Kredit profesi; dan [g] Kredit perumahan.

\section{Jenis-jenis Pembiayaan}

Seperti yang telah dijelaskan pada sub-bab sebelumnya, penyaluran dana atau pembiayaan pada bank syariah terbagi empat yaitu; [a] Pembiayaan dengan prinsip jual-beli; [b] Pembiayaan dengan prinsip bagi hasil; [c] Pembiayaan dengan akad pelengkap; [d] Pembiayaan dengan prinsip sewa. ${ }^{22}$

\section{Jaminan Kredit}

Seperti dijelaskan sebelumnya bahwa didalam menjalankan suatu usaha apa pun tertentu mengandung suatu tingkat kerugian. Resiko ini dapat saja terjadi akibat suatu musibah yang tidak dapat dielakkan seperti terkena bencana alam, namun resiko yang paling fatal adalah akibat nasabah yang mampu tetapi tidak mau membayar kewajibannya. Adanya resiko kerugian dimana nasabah tidak sanggup lagi untuk membayar semua kewajibannya baik untuk sementara waktu atau selamanya harus segera diantisipasi oleh dunia perbankan. Kalau tidak maka sudah dapat dipastikan kredit tersebut macet alias tidak terbayar lagi. Ketidakmampuan nasabah dalam melunasi kreditnya, dapat ditutupi dengan suatu jaminan kredit. Fungsi jaminan kredit adalah untuk melindungi bank dari kerugian, dengan adanya jaminan kredit dimana nilai. Jaminan, biasanya melebihi nilai kredit maka bank akan aman. Bank dapat mempergunakan atau menjual jaminan kredit untuk menutupi apabila kredit maka bank akan aman. Bank dapat mempergunakan atau menjual jaminan kredit untuk menutupi apabila kredit yang diberikan macet kredit untuk menutupi apabila kredit yang diberikan macet. Jaminan kredit juga akan melindung bank dari masalah yang nakal. Hal ini disebabkan tidak sedikit nasabah yang mampu tetapi tidak mau membayar kreditnya yang paling penting dalam jaminan kredit adalah mengikat nasabah untuk segera melunasi utang-utangnya, nasabah akan terikat dengan bank. Mengingat jaminan kredit akan disita oleh bank apabila nasabah tidak mampu membayar. Untuk masalah-masalah khusus kredit dapatlah diberikan tanpa jaminan. Hal ini dengan berbagai pertimbangan yang matang misalnya untuk jumlah yang kecil atau kredit sosial.

Dalam praktiknya yang dapat dijadikan jaminan kredit oleh calon debitur adalah sebagai berikut; [a] Jaminan dengan barang-barang seperti, tanah; [b] Jaminan surat berharga seperti, Sertifikat saham; [c] Jaminan orang atau perusahaan, yaitu jaminan yang diberikan oleh seseroang atau perusahaan kepada bank terhadao fasilitas kredit yang diberikan; [d] Jaminan asuransi, yaitu bank menjaminkan kredit tersebut kepada pihak asuransi, terutama terhadap pisik obyet kredit. ${ }^{23}$

\section{Jenis Pembebanan Suku Bunga Kredit}

Setiap nasabah yang memperoleh fasilitas kredit dari bank akan dikenakan kewajiban membayar kembali. Pembayaran kewajiban tersebut dilakukan setiap periode apakah harian, mingguan atau bulanan. Pemkbayaran ini lebih dikenal dengan nama angsuran.

\footnotetext{
23 Karim, Adiwarman, op, cit, hlm.
} 
Dalam setiap angusran yang dibayar oleh nasabah sudah termasuk pokok pinjaman ditambah bunga yang harus dibayar. Jumlah angsuran yang dibayar setiap periode berbeda tergantung dari jenis pembebanan suku bunga yang dilakukan oleh bank. Pembebanan jenis suku bunga oleh bank adalah dengan memperhatikan jenis kredit yang dibayari, kemudian juga yang menjadi pertimbangan bank dalam menentukan pembebanan suku bunga adalah tingkat resiko dari masing-masing jenis kredit.

Dewasa ini terdapat 3 model pembebanan suku bunga yang sering dilakukan oleh bank. Adapun model pembebanan suku bunga yang dimaksud adalah sebagai berikut ${ }^{24}$

Flate rate, merupakan perhitungan suku bunga yang tetap setiap periode, sehingga jumlah angsuran (cicilan) setiap periode pun tetap sampai pinjaman tersebut lunas. Perhitungan suku bunga adalah dengan mengalikan \% bunga perperiode dikali dengan pinjaman.

\begin{tabular}{ll|} 
Suku Bunga $=\quad \frac{\% \mathrm{x} \text { Pinjaman }}{\text { Tahun }}$ \\
\hline
\end{tabular}

Sliding Rate, merupakan perhitungan suku bunga yang dilakukan dengan mengalikan persentase suku bunga per periode dengan sisa pinjaman sehingga jumlah suku bunga yang dibayar debitur semakin menurun, akibatnya angsuran yang dibayarpun menurun jumlahnya.

Floating Rate, merupakan perhitungan suku bunga yang dilakukan sesuai dengan tingkat suku bunga pada bulan yang bersangkutan. Dalam perhitungan model ini, suku bunga dapat naik, turun atau tetap setiap periodenya. Begitu pula dengan jumlah angsuran yang dibayar sangat tergantung dari suku bunga pada bulan

24 Kasmir, Manajemen Perbankan, op, cit, hlm. hlm. 80 - 81 yang bersangkutan

\section{Penetapan Marjin Keuntungan dan Nisbah bagi Hasi Pembiayaan}

Setelah mempelajari berbagai macam produk pembiayaan bank syariah, kita akan memasuki pembahasan tentang bagaimana menetapkan tingkat keuntungan dan nisbah bagi hasil pembiayaan sehingga bank syariah dapat memperoleh return yang maksimal. Dengan demikian, bank syariah dapat pula memberikan bagi hasil yang maksimal kepada dana pihak ketiga karena semakin tinggi tingkat keuntungan yang diperoleh bank, semakin tinggi pula bagi hasil yang diberikan bank kepada dana pihak ketiga, begitu pula sebaliknya. Idealnya, selain dituntut untuk mematuhi aturan-aturan syariah, bank syariah juga diharapkan mampu memberikan bagi hasil kepada dana pihak ketiga minimal sama dengan, atau bahkan lebih besar, dari pada suku bunga yang berlaku di bank konversional serta menerapkan marjin keuntungan pembiayaan yang lebih rendah dari pada suku bunga kredit bank konvensional.

Untuk merealisasikan konsep ideal tersebut, bank syariah harus dikelola secara aptimal berlandaskan prinsip amanah, sidq, fatonah, dan tabliqh, termasuk dalam hal kebijakkan penetapan marjin keuntungan dan nisbah bagi hasil pembiayaan.

Bank syariah menerapkan marjin keuntungan terhadap produkproduk pembiayaan yang berbasis natural certainty contracts (NOC), yakni akad bisnis yang meberikan kepastian pembayaran, baik dari segi jumlah (Amount) maupun waktu (timing), seperti pembiayaan murabahah, ijarah, salam dan istishna. Salam teknis, yang dimaksud dengan marjin keuntungan adalah persentase tertentu yang diterapkan pertahun perhitungan marjin keuntungan secara harian, maka jumlah hari dalam setahun ditetapkan 360 hari, perhitungan marjin 
keuntungan secara bulanan, maka setahun ditetapkan 12 bulan. ${ }^{25}$

Pada umumnya, nasabah pembiayaan melakukan pembayaran secara angsuran. Tagihan yang timbul dari transaksi jual beli dan atau sewa berdasarkan akad murabah, salam istishna dan atau ijarah disebut sebagai piutang. Besarnya piutang tergantung pada plafond pembiaya, yakni jumlah pembiayan (harga beli ditambah harga pokok) yang tercantum didalam perjanjian pembiayaan. Harga jual adalah penjumlahan harga beli / harga pokok/ harga perolehan bank dan marjin keuntungan.

\begin{tabular}{|c|c|c|c|c|}
\hline $\begin{array}{l}\text { Referensi } \\
\text { marjin keuntungan }\end{array}$ & + & $\begin{array}{l}\text { Harga beli } \\
\text { (Harga } \\
\text { pokok bank) }\end{array}$ & $=$ & Harga jual \\
\hline
\end{tabular}

Angsuran harga jual terdiri dari angsuran harga beli/harga pokok dan angsuran marjin keuntungan. Pengakuan angsuran dapat dihitung dengan menggunakan empat metode, yaitu; [a] Metode marjin keuntungan menurun; [b] Metode marjin keuntungan rata-rata; [c] Metode marjin keuntungan flat; [c] Metode marjin keuntungan annuitas.

\section{Kesimpulan}

Bank syari'ah yang beroperasi dengan sistem bagi hasil tidak boleh menggunakan bunga dalam setiap operasinya. Ini terbukti cukup tangguh dari pengaruh gejolak moneter dan terkenal dengan kebijakan pemerataan dalam akses modal dan usaha, meskipun ternyata tidak luput dari kelemahan yang melekat padanya, seperti kurangnya fasilitas pendukung, kurang berani mengambil resiko dalam pembiayaan jangka panjang dan yang beresiko tinggi serta adanya moral hazard. Begitu juga dengan bank konvensional yang terkenal dengan kontrak- kontraknya yang berdasarkan sistem bunga dan penyediaan fasilitas yang begitu cukup baik juga tidak luput dari kelemahan yang melekat padanya, seperti rentan terhadap gejolak moneter, adanya proses pemelaratan, ketidakadilan dalam membagi keuntungan dan resiko kerugian. Namun demikian keduanya harus tetap ada dan bersaing dengan sehat dalam membantu pertumbuhan ekonomi dan terciptanya kesejahteraan ekonomi masyarakat.

\section{Bibliografi}

Karim, Adiwarman, Bank Islam, (Jakarta: Rajawali Press, 2007).

Kasmir, Dasar-Dasar Perbankan, (Jakarta: Rajawali Press, 2002).

Kasmir, Manajemen Perbankan, (Jakarta: Rajawali Press, 2000).

Kasmir, Pemasaran Bank, (Jakarta: Prenada Media, 2004).

Raachibini, Didik, Bank Indonesia Menuju Indepedensi Bank Sentral, (Jakartaa: Mardimulyo, 2009).

Undang-undang No. 10 tahun 1998 tentang Perbankan. 